\title{
From Antisocial to Prosocial Manhood: SHAKESPEARE'S RESCRIPTING OF MASCULINITY IN AS YOU LIKE IT
}

\author{
MARK BRACHER
}

\begin{abstract}
Cognitive psychologists have established that people's internalized gender scripts, which play a large role in constituting people's identity, or sense of self, and thus in motivating and directing their behaviors, are to a significant degree internalizations of the gender scripts circulating in one's culture. Shakespeare's plays offer a rich array of masculinity scripts for examination and either rejection or adoption. More specifically, by revealing the respective motives and consequences of various masculinity scripts, the plays embody a tacit but powerful critique of dominant masculinity (most obviously in the tragedies and histories) and an embrace of alternative masculinities, most notably in the comedies. As You Like It stands out among the comedies as offering the most cogent critique of dominant masculinity together with a strong case for embracing alternative masculinity scripts that are at once "truer to nature", less harmful to others, and more fulfilling to their bearers themselves.
\end{abstract}

Why should scholars, teachers, and students concern themselves with exploring representations of masculinity in literary texts, particularly when those texts were produced in times and places quite distant and different from their own? The only defensible answer - that is, the only answer that can justify the expenditure of human and economic resources on such explorations - is that such endeavors can in some way be of benefit to us today. The key question concerning a text's representations of masculinity, therefore, is can they function in any 
way to help current audiences negotiate more effectively the vexed issue of masculinity that is implicated in so many personal and social problems afflicting people today?

Prima facie evidence that Shakespeare's As You Like $I t^{1}$ might be capable of providing such assistance comes in two forms. First is the fact that the play offers exemplars of multiple alternative masculinities for its audiences to reflect on, identify with, and respond to. Bruce R. Smith notes in Shakespeare and Masculinity that "At least five ideal types offer themselves for emulation in Shakespeare's scripts: the chivalrous knight, the Herculean hero, the humanist man of moderation, the merchant prince, and the saucy jack", ${ }^{2}$ and he points out that these representations provide Shakespeare's audiences with the opportunity to alter their understanding of and/or their identity as men. ${ }^{3}$

A second body of evidence for the play's potential to assist us with our current struggles regarding masculinity lies in the fact that during Shakespeare's time there was a fierce debate in the royal court and the wider public sphere over the relative virtues of the heroic and the humanist models of masculinity. In Shakespeare on Masculinity Robin Headlam Wells, noting that "all [Shakespeare's] tragedies and most of [his] comedies and histories inevitably concern themselves in one way or another with the question of "manhood and honour", 4 observes that during the time Shakespeare was writing, opposing political alliances and public policies in England, including conflict over whether to wage war against Spain, were determined to a significant degree by opposing forms of masculinity. The anti-war side of this political divide was motivated by the Renaissance humanist ideal of masculinity, espoused by figures such as Erasmus and More, which valorized learning, public service, and the pursuit of a just society. ${ }^{5}$ The pro-war side, which included men such as Sidney and Essex, was motivated by the heroic ideal of masculinity, which valorized physical courage,

\footnotetext{
${ }^{1}$ All citations and references to acts, scenes, lines and verses refer to The Arden Shakespeare edition (3rd series) of As You Like It, ed. Juliet Dusinberre, London: Bloomsbury, 2007.

${ }^{2}$ Bruce R. Smith, Shakespeare and Masculinity, New York: Oxford University Press, 2000, 44 .

${ }^{3}$ See ibid., 120-22, 148.

${ }^{4}$ Robin Headlam Wells, Shakespeare on Masculinity, New York: Cambridge University Press, 2000, 6.

${ }^{5}$ See ibid., 14.
} 
competitive assertiveness, military prowess, and a politics of violence. $^{6}$

The stakes of this conflict between opposing masculinities were high: "the conflicting political positions signaled by such coded phrases as 'courage-masculine' and 'manly virtue' caused deeper divisions in Elizabeth's and James' Privy Councils than any other topic of public debate in late-Elizabethan and early-Stuart England", Wells reports: "Those conflicts very nearly resulted in the deposition of a reigning monarch, and later provoked a bitter and embarrassing public rift between her successor and the crown prince." "Four hundred years later, this conflict between opposing masculinities has by no means been settled, and the continued presence in our era of swaggering, bellicose politicians demands that we continue to address it. The question, then, is how As You Like It might help us do so in a productive manner.

In order to answer this question I will not only argue that a) Shakespeare's plays offer a rich array of masculinity scripts for examination and either rejection or adoption and that b) these plays - by revealing the respective motives and consequences of various masculinity scripts - embody a tacit but powerful critique of dominant masculinity (most obviously in the tragedies and histories) and an embrace of alternative masculinities (most notably in the comedies), but also that c) As You Like It stands out among the comedies as offering the most cogent critique of dominant masculinity together with a strong case for embracing alternative masculinity scripts that are at once truer to nature, less harmful to others, and more fulfilling to their bearers themselves. These alternative, more feminine scripts, I shall argue, are not only less harmful and more fulfilling, they are also truer to nature, in that they acknowledge and enact, rather than repress, a broader range of the human needs, vulnerabilities, and capabilities that are inherent in all men as well as all women.

\section{Masculinity scripts}

\section{Nature, function, and consequences}

The first step in answering the question of how literature, and especially Shakespeare's As You Like It, might help us to overcome opposing and outdated scripts of masculinity is to understand the effects that

\footnotetext{
${ }^{6}$ See ibid., 11-12, 15.

${ }^{7}$ See ibid., 6.
} 
Shakespeare's theatrical script can have on the cognitive scripts that variously constitute and determine readers' definition, understanding, evaluation, and enactment of masculinity. Cognitive scripts are structures of general knowledge that serve as "blueprints for behavior and thus guide both our actions and our understandings of events and behaviors". 8 They "provide us with a general idea of how we are supposed to behave and what is supposed to happen". "A script incorporates both procedural and declarative knowledge and suggests what events are to happen in the environment, how the person should behave in response to these events, and what the likely outcome of those behaviors would be." 10 Gender scripts are structures of knowledge concerning the specific behaviors through which various forms of masculinity and femininity are constituted, performed, and recognized. Our gender scripts thus play a major role in determining those of our behaviors that imply a certain gender identity as well as in our perception and judgments regarding the gender identities of other people. ${ }^{11}$

In performing these functions, gender scripts can produce serious psychological and social problems, and masculinity scripts are major causes of both types of harm. One way gender scripts cause psychological harm is by conflicting with people's experiences of themselves and the world. As second-wave feminists convincingly documented, the gender scripts for women that held sway prior to the 1960s caused considerable psychological suffering for huge numbers of women by prescribing certain behaviors (for example, those of the dutiful wife, mother, and homemaker) and proscribing others (for example, those of an autonomous, assertive career woman and sexual agent). More recently, psychologists have documented that certain masculinity scripts take a severe psychological toll on many men. Terence Real, for example, has explained how masculinity scripts of toughness and

\footnotetext{
${ }^{8}$ Joan D. Atwood, "Social Construction Theory and Therapy Assumptions", in Family Scripts, ed. Joan D. Atwood, New York: Taylor and Francis, 1996, 13.

${ }^{9}$ Joan D. Atwood, Introduction, in ibid., xvi.

${ }^{10}$ L. Rowell Huesmann, "The Role of Social Information Processing and Cognitive Schema in the Acquisition and Maintenance of Habitual Aggressive Behavior", in Human Aggression: Theories, Research, and Implications for Social Policy, eds Russell G. Geen and Edward Donnerstein, San Diego, CA: Academic Press, 1998, 89.

${ }^{11}$ See Laura M. Carpenter, "From Girls into Women: Scripts for Sexuality and Romance in Seventeen Magazine, 1974-1994", The Journal of Sex Research, XXXV/2 (May 1998), 158-68.
} 
impassivity cause considerable psychological pain for the great majority of men and their families by shaming them into denying their feelings of tenderness and vulnerability. ${ }^{12}$

Gender scripts also produce serious social problems in a more direct manner, by prescribing antisocial behaviors and proscribing prosocial ones. Masculinity scripts are particularly culpable on this count. Scripts of competitiveness (do anything to win), honor (never back down or walk away from a fight), control (always be in control of yourself and of the situation), toughness (boys do not cry), and impassivity (never let them see you sweat) continue to lead men to engage in actions that are harmful and unjust - to themselves as well as to others. One team of psychotherapist researchers has identified seven contemporary masculinity scripts that they have found to be common among their male patients. Each of these scripts emanates from and supports the heroic ideal of masculinity as monolithic, inflexible, penetrating, impenetrable, and unyielding. While these scripts can have beneficial effects for self and others when they are enacted in certain circumstances and with the right degree of intensity, they are also often a significant cause not only of the interpersonal and emotional difficulties that lead men to seek help in psychotherapy ${ }^{13}$ but of various social problems as well.

These scripts include the following: a) the tough-guy script, which suppresses or represses tender feelings and awareness of vulnerability and promotes violent behavior; b) the give-'em hell script, which underwrites interpersonal and intergroup forms of physical violence and abusive behaviors; c) the winner script, which promotes competitiveness and the aggression that often accompanies it; d) the strong and silent script, which contributes to fear of intimacy and depression; e) the independent script, which leads men to undervalue relationships and collective endeavors and to see other people as challenges and threats rather than potential sources of comfort and fulfillment; f) the playboy script, which validates exploitation of women and militates against feelings and behaviors of empathy, caring, and attachment, g) the homophobic script, which not only proscribes affectionate feelings and behaviors toward other men but also promotes anti-gay violence

\footnotetext{
${ }^{12}$ Terence Real, I Don't Want to Talk about It, New York: Scribner, 1998.

${ }^{13}$ See James R Mahalik, Matt Englar-Carlson and Glenn E. Good, "Masculinity Scripts, Presenting Concerns, and Help Seeking: Implications for Practice and Training”, Professional Psychology: Research and Practice, XXXIV/2 (April 2003), 124.
} 
by forcing externalization of men's affectionate feelings for other men.

\section{Altering harmful masculinity scripts}

The personal, interpersonal, and social problems produced by these scripts of heroic, dominant masculinity motivate the search for and development of alternative scripts through which one can be a man. As You Like It can be seen as both a product of this search for alternatives on Shakespeare's part and a means of facilitating audience members' discovery and development of alternative, more productive scripts. The play can help its audiences alter their own harmful masculinity scripts by engaging them in some of the same cognitive and emotional processes through which scripts are constructed and reconstructed by socialization, education, and psychotherapy.

As You Like It can help audience members discontinue the use of harmful scripts and replace them with more beneficial scripts by engaging its audiences in the same basic processes that psychotherapists have identified as key to script alteration. These processes include the following: a) providing a safe environment; b) identifying the harmful scripts; c) spelling out the benefits that these scripts produce for the client; d) enumerating the costs incurred through enacting these harmful scripts; e) helping the client become more flexible in enacting these harmful scripts; f) generating alternative, less problematic scripts, and g) reflecting on the implications and consequences of these alternative scripts..$^{14}$

Watching, reading, and performing plays can activate each of these processes. In the first place, reading or watching a play is safe, much less emotionally threatening than directly confronting one's own psychological issues - a fact that has led some therapists to have their patients read literary works that deal with the same problems the patients are facing. Second, plays can represent problematic behavioral scripts that audience members enact or accept, and they can expose the benefits as well as the costs of these scripts to the audience. Plays can also demonstrate for their audiences more flexible, less compulsive ways of enacting these problematic scripts. And finally, and per-

\footnotetext{
${ }^{14}$ For points b) to e), see Mahalik, Englar-Carlson and Good, "Masculinity Scripts, Presenting Concerns, and Help Seeking", 126; for points a) and f), see Atwood, "Social Construction Theory and Therapy Assumptions", 25; and for point g), see ibid., $15-17,25$.
} 
haps most importantly, plays can generate alternative, less problematic scripts for their audiences and help them reflect on their consequences.

How is this done? New scripts are acquired by observing other people enacting certain behaviors in response to particular types of situations. Such acquisition of behavioral scripts occurs as a result of observing their enactment not only in real life but also in media representations, ${ }^{15}$ which includes watching performances of plays on stage or on screen, and even reading the script of the play. Behavioral scripts are solidified by being rehearsed, and this rehearsal can take the form not only of real-life enactment but also of play-acting (as in rehearsing or performing a play), fantasizing the enactment, or simply recalling the enactment. ${ }^{16}$ Solidification of behavioral scripts is promoted by positive reinforcement, including vicarious reinforcement that is, witnessing the positive outcomes of these scripts when they are enacted by other people or characters.

\section{As You Like It's interventions in masculinity scripts}

As You Like It promotes the development of more beneficial and prosocial masculinity scripts by engaging its audiences in all of these script-changing practices. First, the play operates on numerous fronts to expose and undermine its audiences' harmful, antisocial masculinity scripts. It does so by demonstrating the costs of these dominant scripts, which include various harms both to those who attempt to enact the scripts and to those who are the objects of those enactments. Second, the play reveals the positive functions of these harmful scripts and indicates how these positive effects can be maximized and the harmful effects minimized by the selective and judicial restriction of the harmful scripts' enactment to certain specific modes and situations. And finally and most importantly, As You Like It represents less harmful, more beneficial scripts of masculinity, demonstrates their positive consequences, and engages its audiences in constructing and rehearsing these alternative, prosocial scripts.

\footnotetext{
${ }^{15}$ See Huesmann, "The Role of Social Information Processing and Cognitive Schema in the Acquisition and Maintenance of Habitual Aggressive Behavior", 97.

${ }^{16}$ See ibid., 95, 98 .
} 


\section{Costs of heroic masculinity scripts}

Costs of heroic masculinity scripts include social, political, material, and physical harm to self and others as well as various kinds of psychological harm, including vulnerability, insecurity, anxiety, transience, inauthenticity, self-deception, and hyper-defensiveness. As You Like It engages its audiences in vicariously experiencing multiple episodes in which enactments of heroic masculinity scripts produce such harm. The most brutal episodes involve violent physical competition that is in some cases lethal and that is motivated by scripts in which men achieve or preserve honor through competing with and gaining dominance over other men.

The play begins with a physical struggle between Orlando and his older brother Oliver, who has deprived Orlando of the support he promised their dying father he would provide. That struggle is followed by Oliver's enlisting Duke Frederick's professional wrestler Charles - the quintessence of masculine virility, toughness, and brutality - to permanently disable Orlando, if not kill him, in the next day's wrestling competition. In the following scene, the negative consequences of this masculinity script are driven home to the audience when Le Beau reports to Rosalind and Celia that Charles has just wrestled three brothers and left them dying:

The eldest of the three wrestled with Charles, the Duke's wrestler, which Charles in a moment threw him, and broke three of his ribs, that there is little hope of life in him, So he serv'd the second, and so the third. Yonder they lie, the poor old man, their father, making such pitiful dole over them that all the beholders take his part with weeping.

The weeping of the father and the spectators cues Shakespeare's audience as to their proper response to the harm inflicted by the script of violent masculinity. Later in the same scene, it is Charles himself who is victimized by this Herculean script, when, after threatening Orlando with the same fate he visited on the brothers ("Come, where is this young gallant that is so desirous to lie with his mother earth", I.ii.19192), he is thrown by Orlando and rendered speechless and unable to walk.

Such episodes can work to make audience members less inclined to enact or condone the Herculean masculinity script and the physical violence it entails. One major reason people (mainly boys and men) 
engage in physical violence is because their dominant masculinity scripts connect such behavior with positive outcomes (for example, security, honor, wealth). As L. Rowell Huesmann explains, "more aggressive individuals have encoded in memory more extensive, well connected networks of social scripts emphasizing aggressive problem solving". ${ }^{17}$ Such individuals often "misperceive the likely consequences of aggressive acts simply because their scripts are inaccurate in predicting consequences for the present situation". ${ }^{18}$ The presence and power of such scripts derive in significant measure from observing them in mass media:

Research on media violence and aggression provides ... compelling evidence of that process [of encoding violence scripts in memory]. Copycat crimes and the well-known contagion of suicide ... provide some of the clearest examples of specific aggressive scripts being acquired by adults through observation from media. More importantly from a scientific standpoint perhaps, numerous laboratory and field experiments ... have demonstrated the encoding of specific scripts from such observations. ${ }^{19}$

If observation of fictional representations of violence scripts with positive outcomes enhances their encoding, accessibility, and retrieval, the same is no doubt true of observations of violence scripts with negative outcomes, such as those with which As You Like It begins. Repeated encounters with such episodes in which physical violence produces disablement, suffering, and death should enhance the strength and accessibility of audiences' competition $\rightarrow$ violence $\rightarrow$ negative consequences scripts vis-à-vis their competition $\rightarrow$ violence $\rightarrow$ positive consequences scripts and thus make them more cognizant of the negative consequences of such scripts and hence less likely to enact, honor, or even condone them when they encounter them.

In addition to promoting the establishment of a competition $\rightarrow$ violence $\rightarrow$ negative consequences script in readers, As You Like It also works to extend this script backwards, through envy and pride, to masculine honor, and to incorporate violence by proxy as a goal and negative consequence, thus connecting masculine honor to multiple forms of injustice, suffering, and death. The dominant masculinity $\rightarrow$

\footnotetext{
${ }^{17} \mathrm{Ibid} ., 91$.

${ }^{18}$ Ibid., 92-93.

${ }^{19}$ Ibid., 97.
} 
honor/pride $\rightarrow$ competition $\rightarrow$ envy $\rightarrow$ treachery script is presented first in statements made by Duke Frederick and Oliver. When Oliver soliloquizes at the end of the opening scene that he hates Orlando but does not know why, his subsequent ruminations indicate clearly to the audience that the reason is envy:

I hope I shall see an end of him; for my soul, yet I know not why, hates nothing more than he. Yet he's gentle, never schooled and yet learned, full of noble device, of all sorts enchantingly beloved; and indeed so much in the heart of the world, and especially of my own people, who best know him, that I am altogether misprized. But it shall not be so long.

That Frederick is following the same dominant masculinity $\rightarrow$ honor/pride $\rightarrow$ competition $\rightarrow$ envy $\rightarrow$ treachery script is indicated in the following scene, when he says to Orlando, "The world esteemed thy father honorable, / But I did find him still mine enemy" (I.ii.214-15). Shortly thereafter Duke Frederick enacts this script on Rosalind, whom he banishes and threatens to kill because he is envious that she is more admired and beloved by the people than his daughter Celia. This envy is made clear by Le Beau, who informs Orlando and the audience that

... of late this Duke

Hath ta'en displeasure 'gainst his gentle niece,

Grounded upon no other argument

But that the people praise her for her virtues,

And pity her for her good father's sake;

Duke Frederick confirms that envy is motivating his treachery when, in response to Celia's objection, he explains:

She is too subtle for thee, and her smoothness,

Her very silence, and her patience

Speak to the people and they pity her.

Thou art a fool. She robs thee of thy name,

And thou wilt show more bright and seem more virtuous

When she is gone. 
Frederick then turns to Rosalind and, invoking the masculine honor that is motivating him, repeats his lethal threat:

You, niece, provide yourself;

If you outstay the time, upon mine honour, And in the greatness of my word, you die.

(I.iii.87-89)

The dominant masculinity $\rightarrow$ honor/pride $\rightarrow$ competition $\rightarrow$ envy $\rightarrow$ treachery script is repeated one short scene later in Oliver's scheme against Orlando. Adam warns Orlando that his elder brother, enraged over the accolades Orlando is receiving after having defeated Charles, intends to kill him:

Your brother ...

Hath heard your praises, and this night he means

To burn the lodging where you used to lie,

And you within it. If he fail of that,

He will have other means to cut you off;

(II.iii.19-25)

Act III begins with Duke Frederick following this same script issuing an ultimatum to Oliver:

Find out thy brother, wheresoe'er he is;

Seek him with candle; bring him dead or living

Within this twelvemonth, or turn thou no more

To seek a living in our territory.

This script of dominant masculinity $\rightarrow$ honor/pride $\rightarrow$ competition $\rightarrow$ envy $\rightarrow$ treachery is further reinforced in Act II by Duke Senior and his men, whose exile is a result of Duke Frederick's enactment of it. The Act begins with Duke Senior reflecting,

Now, my co-mates and brothers in exile, Hath not old custom made this life more sweet Than that of painted pomp? Are not these woods More free from peril than the envious court? 
Later Amiens echoes the sentiment in a song that ends, "Here shall he see no enemy / But winter and rough weather" (II.v.6-7), a refrain that is repeated later in the scene by the Duke's entire entourage. And Amiens concludes the act with another song contrasting the treachery of the court with its absence in the forest:

Blow, blow, thou winter wind,

Thou art not so unkind

As man's ingratitude:

Thy tooth is not so keen,

Because thou art not seen,

Although thy breath be rude.

Hey-ho, sing hey-ho, unto the green holly.

Most friendship is feigning, most loving mere folly.

Then hey-ho, the holly!

This life is most jolly.

Freeze, freeze, thou bitter sky,

That dost not bite so nigh

As benefits forgot:

Though thou the waters warp,

Thy sting is not so sharp

As friend remembered not.

(II.vii.175-90)

Such repeated reminders of the treachery, injustice, and suffering entailed by heroic masculinity and its envious quest for dominance, combined with the repeated enactments of such treachery by the envious Oliver and Duke Frederick, promote the establishment of the dominant masculinity $\rightarrow$ honor/pride $\rightarrow$ competition $\rightarrow$ envy $\rightarrow$ treachery script in audiences and thus reduce their inclination to either pursue or approve the pursuit of dominance. That is, whenever audience members think of or feel drawn to pursue honor through the dominance of someone else, they are more likely to be aware not only of the positive consequence of honor but also of negative consequences such as envy, enmity, treachery, suffering, and injustice, and this awareness will make them less inclined to enact or approve the enactment of the script of masculine dominance - either in interpersonal relations or in collective social actions, including politics. 
Heroic masculinity as defensive masquerade

In addition to promoting the development of cognitive scripts connecting heroic, dominant masculinity with multiple negative outcomes, $A s$ You Like It also induces the formation of inferential scripts for recognizing dominant, heroic masculinity as a cover, façade, or masquerade disguising an impotent, "unmasculine" core. This script is developed most centrally through the audience's multiple and extended experiences of Ganymede in full cognizance that "he" is really Rosalind (and the further awareness in Shakespeare's original audiences that Rosalind was really a boy actor). The audience is instructed early on that Ganymede's swagger and bluster, rather than being a manifestation of an underlying masculine self, are efforts to disguise and thus protect the vulnerable feminine self that is enacting them. And at the same time, Shakespeare tells his audience explicitly, through Rosalind's continued musings, that this is precisely the case with many hypermasculine men:

Were it not better,

Because that I am more than common tall, That I did suit me all points like a man?

A gallant curtle-axe upon my thigh, A boar-spear in my hand, and - in my heart Lie there what hidden woman's fear there will We'll have a swashing and a martial outside, As many other mannish cowards have

That do outface it with their semblances.

(I.iii.112-19; emphasis added)

This masquerade, we are further shown, may itself be responsible, through the defense of reaction formation, for any actual qualities of heroic masculinity that a person, whether male or female, may develop. This point is made when Rosalind says to the fatigued and flagging Celia: "I could find it in my heart to disgrace my man's apparel and to cry like a woman, but I must comfort the weaker vessel, as doublet and hose ought to show itself courageous to petticoat. Therefore courage, good Aliena" (II.iv.4-8). Thus primed, Shakespeare's audience is more capable of seeing all instances of "a swashing and a martial outside" - both in the play and in life - as at least potentially mere "semblances" covering for "mannish cowards". And we are guided to this conclusion with various degrees of explicitness. When 
Orlando accosts Jaques and Duke Senior with sword drawn demanding food, Duke Senior recognizes that this aggression is a function of his vulnerability rather than a manifestation of his true nature. "Art thou thus boldened, man, by thy distress?" (II.vii.92), he asks Orlando, and Orlando replies in the affirmative: "The thorny point / Of bare distress hath ta'en from me the show / Of smooth civility" (II.vii.9597).

Touchstone's belligerence is also revealed to be a bluff, and even Oliver's and Frederick's violence turns out, at the end of the play, to have been hiding a more authentic vulnerable self. By witnessing multiple instances of heroic, dominant masculinity being little more than a defensive disguise of an underlying vulnerability, audience members begin to acquire a masculinity script that inclines them, whenever they encounter or think of bluster, bravado, belligerence, or other dominating behavior, to infer or suspect that this behavior is not a manifestation of the man's substance or true self but rather a façade beneath which lies a "girl" - that is, a vulnerable, "non-masculine" self. In promoting the development of this vulnerability $\rightarrow$ dominantmasculinity façade script, As You Like It performs a valuable function for us today, for this same disguise is still much in operation, ${ }^{20}$ and we would be better off if we could recognize the frequent instances in which male bravado and aggression - whether in interpersonal relations or in the pubic posturing of a president - are a sign of and defense against an underlying vulnerability: essentially, a frightened "feminine" self.

\section{Touchstone: more flexible enactments of the dominant script}

In addition to undermining the audience's script of dominant, heroic masculinity by interpolating negative consequences, vulnerability, and defensiveness into it, As You Like It also scripts a more flexible, less destructive mode of enacting dominance. This is accomplished through the character of Touchstone, who renounces overt, physical aggression - apparently because he is aware of its potential negative consequences, in the form of physical harm, for himself - and engages instead in sublimated aggression in the form of insults and threats. Touchstone's mode of dealing with his envy is through sublimated aggression, aggression expressed verbally rather than physically. That envy lies behind his aggression is supported by the suggestion that he

\footnotetext{
${ }^{20}$ See Real, I Don't Want to Talk about It.
} 
is unattractive (see III.iii.3), ${ }^{21}$ as well as by the ubiquity of his aggression. This verbal aggression takes four forms. First there is his verbal abuse and manipulation, which he directs against those of less nimble wit than he. He outduels the modest and gentle shepherd Corin with nonsensical verbal gymnastics until Corin surrenders, stating, "You have too much courtly wit for me, I'll rest" (III.ii.67), and then tells Corin he will be damned for breeding sheep (see III.ii.80-82). He corners the naïve country girl Audrey with his sophistries, demeaning her for lack of learning (see III.iii.10-14), calling her a "foul slut" (III.iii.33), declaring that he will marry her, and then indicating to Jaques that a sham marriage would suit him fine insofar as it would enable him to use Audrey sexually and then abandon her (see III.iii.73-85). Later, as he is anticipating his marriage to Audrey the following day, he gratuitously criticizes the singing of Duke Senior's pages after they have performed a song at his request (see V.iii.40-47). Such verbal putdowns allow the envious, competitive man to achieve a form of dominance without doing actual physical harm.

Touchstone's second mode of verbal aggression is the threat, which, like his insults, he is careful to deliver only to individuals who will not respond with physical violence. When William, who is in love with Audrey, appears, Touchstone first confuses him with a sophisticated declaration that he cannot have Audrey (see V.i.40-44) and then pedantically, condescendingly, and bombastically threatens to kill him if he does not withdraw his suit:

Therefore, you clown, abandon (which is, in the vulgar, 'leave') the society (which in the boorish is 'company') of this female (which in the common is 'woman'); which together is: 'abandon the society of this female', or, clown, thou perishest! Or to thy better understanding, diest. Or (to wit) I kill thee, make thee away, translate thy life into death, thy liberty into bondage. I will deal in poison with thee, or in bastinado or in steel. I will bandy with thee in faction; I will o'errun thee with policy. I will kill thee a hundred and fifty ways! Therefore tremble and depart.

${ }^{21}$ Dusinberre notes that Touchstone's unattractiveness would have been prominent if he was played by "Shakespeare's clown Robert Armin, a man of diminutive stature and grotesque appearance" (Shakespeare, As You Like It, ed. Dusinberre, 265, n.3). 
Like insults, such bullying enables envious, competitive men to dominate without doing physical harm, as long as their victims accede to their demands as William does.

In other cases, where the targets of his verbal abuse and threats might be less docile, Touchstone manages to avoid physical violence by obliquely criticizing them through their appearance or actions but not directly impugning their character. In bragging to Jaques that he has been a courtier, Touchstone declares, "I have had four quarrels and like to have fought one" (V.iv.46-47). When asked how he managed to avoid fighting in that instance, he responds, "Faith, we met and found the quarrel was upon the seventh cause" (V.iv.49-50), or, as he explains:

Upon a lie seven times removed $-\ldots$ as thus, sir. I did dislike the cut of a certain courtier's beard. He sent me word if I said his beard was not cut well, he was in the mind it was. This is called the 'retort courteous'. If I sent him word again it was not well cut, he would send me word he cut it to please himself. This is called the 'quip modest'. If again it was not well cut, he disabled my judgment. This is called the 'reply churlish'. If again it was not well cut, he would answer I spake not true. This is called the 'reproof valiant'. If again it was not well cut, he would say, I lie. This is called the 'countercheck quarrelsome' - and so to the 'lie circumstantial' and the 'lie direct'.

(V.iv.68-81)

When Jaques asks him, "And how oft did you say his beard was not well cut?" Touchstone responds, "I durst go no further than the lie circumstantial, nor he durst not give me the lie direct; and so we measured swords and parted" (V.iv.82-86). Violence is avoided in this case because neither Touchstone nor his adversary directly impugns the other's character: just as Touchstone restricts his criticism to the courtier's beard, so the courtier restricts his criticism to Touchstone's judgment and behavior ("You lie") and refrains from assailing his character by directly calling him a liar.

One can even call the other a liar and still avoid violence, Touchstone says, if one frames the accusation as a conditional. He recalls a quarrel that an entire panel of judges was unable to resolve: "but when the parties were met themselves, one of them thought but of an 'if': as, 'if you said so, then I said so'; and they shook hands and swore brothers. Your 'if' is the only peacemaker; much virtue in 'if'" (V.iv.97101). This use of the conditional accusation helps to avoid violence in 
two ways. First, it avoids the kind of direct accusation that often results in violence. It allows one to assume a position of dominance vis$\grave{a}$-vis the other without actually besmirching the other's character and thus risking severe retaliation. And second, the conditional prevents one from simply assuming that the other person has in fact done what the conditional posits. This move is a basic technique of aggressionreduction programs, which teach hyper-aggressive individuals to resist assuming that the other's actions are a product of hostile intentions. ${ }^{22}$ Instead of assuming, "Your comment (or action) implies that I am such and such; therefore I must attack you in order to defend my self", subjects are taught to think, "If your intentions were hostile, they implied that I am such and such, and therefore I would need to attack you to defend my self, my honor". While this and Touchstone's three other modes of verbal aggression are by no means admirable, his basic masculinity script (pridelenvy $\rightarrow$ verbal aggression $\rightarrow$ verbal putdown $\rightarrow$ psychological dominance) is nonetheless preferable to the heroic, chivalric masculinity scripts of Oliver, Duke Frederick, and Charles, which result in physically harming people and even killing them.

\section{Alternative scripts: empathic, relational masculinity}

As You Like It not only moderates, transvalues, and renders ineffectual our scripts of heroic, dominant masculinity; it also offers alternative masculinity scripts that are more beneficial both personally and socially - personally because they involve acceptance rather than repression of vulnerability and other qualities inherent in all humans, and socially because they entail accord and peace rather than conflict and violence. At the core of this alternative masculinity script is the quest to actualize an open relational self of love, empathy, and altruism instead of the closed monadic self of self-sufficiency, selfishness, and dominance. ${ }^{23}$ The initial, and paradigmatic, instance of this script in the play is the relationship between Rosalind and Celia - a fact indicating that the relational self and its scripts are traditionally coded as feminine and that women are more adequately socialized to embrace and enact their relatedness, empathy, and selflessness than men are. Celia

\footnotetext{
${ }^{22}$ See Cynthia Hudley and Sandra Graham, "An Attributional Intervention to Reduce Peer-directed Aggression among African-American Boys", Child Development, LXIV/1 (February 1993), 124-38.

${ }^{23}$ For a detailed account of the play's exposition of these two types of self, see Mark Bracher, "Contrary Notions of Identity in As You Like It", Studies in English Literature, XXIV/2 (Spring 1984), 225-40.
} 
articulates the empathy experienced by the relational self when she chides Rosalind for feeling despondent over the exile of her father: "If my uncle, thy banished father, had banished thy uncle, the Duke my father, so thou hadst been still with me I could have taught my love to take thy father for mine. So wouldst thou, if the truth of thy love to me were so righteously tempered as mine is to thee" (I.ii.9-14). Thus instructed, Rosalind replies, "Well, I will forget the condition of my estate to rejoice in yours" (I.ii.15-16). In the following scene, Celia enacts the relational self when she responds to her father's banishment of Rosalind by telling him, "Pronounce that sentence then on me, my liege; / I cannot live out of her company" (I.iii.82-83), and declaring to Rosalind, "thou and I am one" (I.iii.94).

But the play indicates in several ways that the need for relationship is not just a feminine characteristic but a universal human one that is absent only when it is overridden by the unnatural contrivances of civilization, epitomized by the court. Many of the men in the play who are not associated with the court are more interested in peacefully coexisting with others than in dominating them. Three men of the forest - Corin, Silvius, and William - are gentle and peaceful. The shepherd Corin (the feminine version of which, Corinne, means maid) responds to Touchstone's insults and arrogance with dignity and equanimity and declares himself to be a man of modesty and empathy rather than pride and envy: "Sir, I am a true labourer. I earn that I eat, get that I wear; owe no man hate, envy no man's happiness; glad of other men's good, content with my harm; and the greatest of my pride is to see my ewes graze and my lambs suck" (III.ii.70-74).

The other shepherd, Silvius, likewise shows himself to be a man of love and self-effacement rather than pride and aggression. When Phoebe, the unreciprocating object of his love, condescends to allow him in her company, he responds:

So holy and so perfect is my love,

And I in such a poverty of grace,

That I shall think it a most plenteous crop

To glean the broken ears after the man

That the main harvest reaps. Loose now and then

A scattered smile, and that I'll live upon.

(III.v.100-105) 
And when the country youth William (perhaps played by Shakespeare himself) is threatened with death by Touchstone if he does not abandon his suit of Audrey, rather than enacting the script of chivalric, heroic masculinity and responding to the attack on his honor with violence, to Audrey asking him to depart, he simply replies "God rest you merry, sir", and exits (V.i.59).

In addition to these scripts of pastoral masculinity, the play valorizes relational masculinity in the form of service and interdependence. This script is embodied most prominently in the relationship between Adam and Orlando. When Orlando at first refuses to flee from Oliver, explaining that he has no honest means of supporting himself, Adam gives Orlando his life savings and offers to be his servant and to face his end with no regrets:

Master, go on and I will follow thee

To the last gasp with truth and loyalty

... fortune cannot recompense me better

Than to die well and not my master's debtor.

(II.iii.69-70, 75-76)

That Adam bears the name of the male (and human) prototype may be taken to suggest that his empathy, altruism, and generosity are inherent masculine (and human) qualities. Orlando reciprocates this selflessness when he declines Duke Senior's offer of food until he has provided for Adam (see II.vii.131-33).

Duke Senior and his men also evince a relational masculinity based on empathy, mutuality, kindness, and generosity. Duke Senior is the antithesis of the competitive, aggressive, monadic self typified by Oliver and Duke Frederick. Senior's relational self is first announced by Rosalind, who confides that her father "loved Sir Rowland as his soul" (I.ii.224), and Senior defines himself as a relational, loving self rather than a prideful, competitive one when he says to Orlando, "I am the Duke / That loved your father" (II.vii.199-200). Senior enacts the empathy and altruism of the relational self in a number of ways. When Orlando accosts him and his men with sword drawn demanding food, the Duke empathizes with him and responds with kindness and generosity rather than reciprocating Orlando's aggression. His reprimand of Jaques for his failure to do likewise promotes the same script of responding to others' faults with kindness: 
Most mischievous foul sin in chiding sin.

For thou thyself hast been a libertine,

As sensual as the brutish sting itself,

And all th'embossed sores and headed evils

That thou with licence of free foot hast caught

Wouldst thou disgorge into the general world.

(II.vii.64-69)

Duke Senior's comments here suggest that, unlike Jaques (and most other men as well), he is aware of his own negative qualities - aware that he harbors within himself - if only in potentia, or in highly attenuated form - the same negative qualities that he observes in others.

He also realizes, like Jaques, that the world is full of suffering and injustice, about which he feels deeply, but he avoids depression and fatalism and tries to do what he can to mitigate the suffering and injustice (as in "the uses of adversity" speech), even as he recognizes that he is himself implicated in it, as he indicates when he expresses profound empathy for the suffering and death of the deer he kills for food:

Come, shall we go and kill us venison?

And yet it irks me the poor dappled fools, Being native burghers of this desert city, Should in their own confines with forked heads Have their round haunches gored.

This deep and capacious empathy of Duke Senior, together with his opposition to splitting and projection (as indicated by his reprimand of Jaques for projecting his own licentiousness) and his desire to reduce the suffering of others (as he does in helping Orlando and Adam), are indicative of a form of selfhood that in Kleinian psychoanalysis is referred to as the depressive position. Individuals operating from what is called the paranoid-schizoid position are unable to deal with the fact that all people, both oneself and others, are composed "of many parts" (as Orlando says of Rosalind, III.ii.146), both good and bad, and as a consequence they rely heavily on the psychological defense mechanisms of splitting and projection, whereby they split off their own negative qualities from awareness and attribute them instead to certain other individuals or groups, whom they then perceive as all bad. 
This is what Jaques does when he wishes to attribute to others (that is project) the negative qualities that he himself possesses, what the treacherous Duke Frederick does when he accuses Rosalind of treachery and banishes her, and what belligerent politicians often do today. ${ }^{24}$ The depressive position, in contrast, is based on the acknowledgement that no one has a monopoly on either good or evil. In the terms of $A s$ You Like It, everyone is "motley": both oneself and others are composed of many heterogeneous parts, some good and others not so good. The depressive position also involves the recognition that human nature and the human condition are far from ideal but avoids fatalism or wallowing in depression, choosing instead to find a reason to go on living and to help others do the same, as Senior does at the conclusion of his opening speech:

Sweet are the uses of adversity,

Which, like the toad, ugly and venomous,

Wears yet a precious jewel in his head;

And this our life, exempt from public haunt,

Finds tongues in trees, books in the running brooks,

Sermons in stones, and good in everything.

Where many people would see only bad in (literal and metaphoric) "ugly and venomous" toads, and seek to do them harm, Duke Senior seeks and finds some good in them and in everything else as well.

The masculinity of the depressive position embodied by Duke Senior entails social behaviors that are profoundly different from those of the paranoid-schizoid position. From the depressive position it is no longer possible to separate persons into good and evil, since everyone is recognized as containing both kinds of qualities. This means that it is more difficult to do violence to others, or to try to dominate them, when one recognizes that one is inherently no better than they are. In addition, one recognizes that violence in others comes from basic human needs and impulses that oneself harbors, and that in similar cir-

\footnotetext{
${ }^{24}$ For example, it is what George W. Bush did when he accused the perpetrators of the 9/11 attacks as being cowardly and hating freedom, when he himself was missing in action following the attacks and subsequently perpetrated a massive assault on civil liberties. For a more detailed exposition of this point, see Mark Bracher, Social Symptoms: Why We Have Failed to Solve Our Social Problems, and What to Do about It, London: Karnac, 2009.
} 
cumstances one might be inclined to engage in similar behaviors (as Duke Senior recognizes when accosted by the desperate Orlando). And finally, the realization that one has oneself caused harm to others, even if only by living and consuming resources that others also need (or that others are, in the case of food such as the slaughtered deer), leads one to try to make reparations by helping and supporting others rather than trying to dominate them, a switch that both Frederick and Oliver make near the end of the play.

The depressive position thus entails a basic masculinity script that runs directly counter to the basic script of dominating, heroic, chivalric masculinity. In place of the latter's honor/pride $\rightarrow$ competition $\rightarrow$ envy $\rightarrow$ treachery/violence script, Duke Senior's motley, relational masculinity entails the basic script of humility $\rightarrow$ responsibility $\rightarrow$ empathy $\rightarrow$ reparation (generosity, self-sacrifice) $\rightarrow$ atonement, $m u$ tual flourishing.

\section{Scripts for overcoming aggressive, dominating masculinity}

Epiphany and conversion: Oliver and Frederick

In addition to scripting this alternative, reparative masculinity, As You Like It also scripts three basic paths by which one can move away from the paranoid-schizoid position of heroic, aggressive, dominating masculinity and toward the empathic, reparative atonement of relational masculinity. The first and quickest route to reparative masculinity is by way of epiphany and conversion. This is the path taken by Oliver and Frederick. Oliver's epiphany occurs when his life is saved by Orlando, the very man he has been trying to kill, who is wounded in the process. Orlando's selflessness demonstrates to Oliver that his own hatred and violence are "unnatural" (IV.iii.123), and that altruism and kindness are both more noble and more natural than aggression and revenge:

... kindness, nobler ever than revenge,

And nature, stronger than his just occasion,

Made him give battle to the lioness,

Who quickly fell before him, in which hurtling

From miserable slumber I awaked.

(IV.iii.127-31)

Oliver's slumber here is metaphorical as well as literal, referring to his earlier envy and aggression, which rendered his more authentic em- 
pathic and altruistic impulses dormant. He now realizes that this previous self of heroic, dominating masculinity was not his truest, deepest self:

'Twas I but 'tis not I. I do not shame

To tell you what I was, since my conversion

So sweetly tastes, being the thing I am.

(IV.iii.134-36)

Thus enlightened, Oliver falls in love with Aliena/Celia, makes reparation to Orlando by giving him their father's estate, and vows to remain in the forest and "here live and die a shepherd" (V.ii.12).

Duke Frederick's epiphany and conversion come when, on his way to attack Duke Senior in the forest, he comes upon "an old religious man" and, "after some question with him, was converted / Both from his enterprise and from the world" (V.iv.158-60). Following this epiphany and conversion, Frederick, like Oliver, makes reparation,

His crown bequeathing to his banished brother, And all their lands restored to them again

That were with him exiled.

This act, together with Oliver's similar one, provides audience members with an envy/aggression $\rightarrow$ epiphany $\rightarrow$ conversion $\rightarrow$ empathy $\rightarrow$ reparation script through which they can move beyond the paranoid-schizoid position of splitting, projection, and violence.

\section{Orlando: training in perspective taking and relationship}

Like Oliver and Frederick, Orlando begins the play enacting the dominant masculinity $\rightarrow$ honor/pride $\rightarrow$ competition $\rightarrow$ envy $\rightarrow$ aggression masculinity script. But his first aggressive actions - his struggling with Oliver over his inheritance and his wrestling with Charles - suggest that in addition to being envious, he is also depressed. As he indicates to Rosalind and Celia when they try to dissuade him from wrestling Charles, he feels alienated, unworthy, and unloved and doesn't really care if he lives or dies:

... if I be foiled there is but one shamed that was never gracious, if killed, but one dead that is willing to be so. I shall do my friends no wrong, for I have none to lament me; the world no injury, for in 
it I have nothing. Only in the world I fill up a place which may be better supplied when I have made it empty.

Orlando's wrestling with Charles thus enacts aggression not only against Charles but against himself, expressing a barely disguised suicide wish that is not only a result of depression but a defense against it as well. The same is true of his initial determination to ignore Adam's warning of Oliver's plot to kill him and remain on Oliver's estate nonetheless - an action that would almost certainly result in his death, according to Adam.

Fortunately, through falling in love with Rosalind, experiencing the generosity, first, of Adam and then of Duke Senior, and finally being trained in perspective taking by Rosalind (posing as Ganymede), Orlando is enabled to overcome the paranoid-schizoid position and the envy, depression, and aggression it entails and embrace instead the depressive position and its reparative action. Orlando's transformation is initiated when he is smitten by Rosalind as she congratulates him on his victory over Charles. At this point, the script of masculine dominance no longer has dominance over him: his victory over the Herculean hero Charles is followed closely by the defeat of the Herculean masculinity script within himself. His love for Rosalind renders him hopelessly inadequate for himself, leading him to realize that he can become whole or strong not through domination of others but only through relationship to them. "O poor Orlando, thou art overthrown!" he declares as Rosalind departs: "Or Charles or something weaker masters thee" (I.ii.248-49). The overthrow of the chivalric ideal of dominant masculinity is further signaled by Celia when she reports to Rosalind that she saw Orlando lying beneath a tree "like a wounded knight" (III.ii.233-34), indicating that his heroic, chivalric masculinity is moribund.

Orlando therefore abandons his quest for heroic, indomitable masculinity and seeks instead to be united with his better half, which requires first of all connecting with his better internal half: extricating himself from his self-involvement and attuning himself to the nature and needs of the other. This process, in turn, requires his recognizing and accepting the other's, and his own, multiplicity and heterogeneity - that is, recognizing and accepting that neither he, nor his love, nor anyone else is simply one thing, either all good or all bad. The encomium to Rosalind that Orlando disseminates in the forest demon- 
strates, however, that he has still not integrated the good and bad aspects of both self and object.

Thus Rosalind of many parts

By heavenly synod was devised,

Of many faces, eyes, and hearts

To have the touches dearest prized.

Heaven would that she these gifts should have,

And I to live and die her slave.

(III. ii.146-51)

These lines indicate that Orlando is still splitting the good qualities off from himself and projecting them onto his love object, whom he idealizes as possessing only wonderful qualities, while rendering himself an abject object, worthy only of being her slave. Such splitting is nonetheless an improvement over the splitting that attributes only negative qualities to the other, for unlike this latter splitting, which facilitates hatred and violence toward the other, Orlando's form of splitting is a provisional way of maintaining awareness of the other's good qualities and thus facilitates the pursuit of relationship and reparative action. ${ }^{25}$

Orlando requires training and practice in order to enter fully into the relationship and reparative action of the depressive position. As contemporary relational therapists emphasize, men who have spent their lives practicing the heroic, Herculean, chivalric scripts of aggression and dominance cannot easily switch into a relational, reparative mode when they encounter the impasse that the former scripts inevitably entail. Rather, they must work to understand and attune themselves to those others with whom they want a meaningful relationship. ${ }^{26}$ This point is made clear by the fact that Orlando is struck dumb by Rosalind's presence and is incapable of responding to her overtures at first (see I.ii.246-47). Hence before he can enter into a fulfilling relationship with her, he must first receive instruction on how to be an adequate partner. "I am he that is so love-shaked", he says to Ganymede/Rosalind: "I pray you tell me your remedy" (III.ii.353-54). Ganymede/Rosalind obliges by training Orlando to be

\footnotetext{
${ }^{25}$ John Steiner, "The Equilibrium between the Paranoid-Schizoid and the Depressive Positions", in Clinical Lectures on Klein and Bion, ed. Robin Anderson, New York: Routledge, 1992, 46-58.

${ }^{26}$ See Real, I Don't Want to Talk about It.
} 
attentive to her wishes, to take her perspective regarding his own actions, and to recognize and feel guilty when he has failed to do so (see IV.i.35-65, 175-84). She also trains him to recognize her negative qualities and integrate them with the positive, warning him that after they are married she will lose the luster produced by his current idealization of her (see IV.i.138-46).

By the end of the play, Orlando has accomplished the most crucial task of psychological integration: his aggression has been integrated with and subordinated to his love, empathy, and altruism. This point is made clear by Oliver's report of Orlando's actions in saving Oliver's life. When Orlando encounters the sleeping Oliver about to be attacked by the hungry lioness, part of him is inclined to abandon Oliver to his fate as just revenge for Oliver's treachery, but this impulse is subordinated to his empathic, reparative impulses:

Twice did [Orlando] turn his back and purposed [to abandon me to the lioness];

But kindness, nobler ever than revenge,

And nature, stronger than his just occasion,

Made him give battle to the lioness.

(IV.iii.126-29)

Orlando's defeat of the lion, which is a companion and hence metonym of Hercules, symbolizes his overcoming of his own dominating, Herculean masculinity, just as his scaring away of the serpent that is about to enter Oliver's open mouth symbolizes his defeat of his own wicked impulses. His ability to subordinate his own aggressive impulses to his altruistic, reparative impulses can be seen as the result of his encounter with good external objects, in the form of Rosalind, Adam, and Duke Senior, which contribute to and help him own and consolidate his good internal objects ${ }^{27}$ and integrate their qualities into his sense of self. The script for this route that Orlando takes to achieve the depressive position is the following: splitting/idealization of the other (falling in love) $\rightarrow$ encounter with good external objects $\rightarrow$ relationship training $\rightarrow$ integration of empathy and subordination of aggression $\rightarrow$ reparation and relational commitment (marriage).

\footnotetext{
${ }^{27}$ This consolidation includes also his father, of whom he says to Oliver at the beginning of the play, "I have as much of my father in me as you" (I.i.46-47).
} 
Jaques: achieving the depressive position

In Jaques, Shakespeare presents a third script for attaining the relational, reparative masculinity of the depressive position. Instead of repressing his vulnerability and externalizing it onto others by dominating them either physically or verbally, Jaques struggles to acknowledge not only his vulnerability but also his imperfections. This struggle is evident in his vacillation between melancholy and aggression, and this vacillation indicates that both states are responses to vulnerability and imperfection of both self and world.

When he first appears in the play, Jaques is immersed in melancholy, importuning Amiens to keep singing so that he can extend his melancholy state (see II.v.8-12). As they part, he indicates to Amiens, "I'll go sleep if I can; if I cannot, I'll rail against all the first-born of Egypt" (II.v.53-54). Both the desire to sleep and the inability to do so are symptoms of depression (which is a function of the paranoidschizoid position rather than the depressive position), while his fallback position of aggression (in verbal form, against either gypsies or Duke Senior's band of metaphorical gypsies) is a form of manic defense against the depressive position. ${ }^{28}$ And indeed, when he reappears a few minutes later, he is well immersed in this manic alternative. Having just witnessed Touchstone railing against the "miserable world" (II.vii.13), he has resonated with Touchstone's sublimated verbal aggression, which has lifted him out of his depression. Thinking he has found a solution to his angst, he is determined to emulate Touchstone and, by assuming the manner (and motley attire) of the fool, unleash his aggression with impunity: "cleanse the foul body of th'infected world" (II.vii.60).

This plan to defend against his own vulnerability and imperfection by projecting it into "the foul body of th'infected world" is cut short, however, by a decisive intervention from Duke Senior, who, operating much like a psychoanalyst, confronts Jaques with his projection and the personal failings that it is defending against:

Most mischievous foul sin in chiding sin.

For thou thyself hast been a libertine,

As sensual as the brutish sting itself,

And all th'embossed sores and headed evils

${ }^{28}$ See Shakespeare, As You Like It, ed. Dusinberre, 214, n.54. 
That thou with licence of free foot hast caught, Wouldst thou disgorge into the general world.

Jaques protests that his verbal attacks will be entirely just and deserved, but he is interrupted by the sudden entrance of Orlando, and when he resumes his ruminations some mere fifty lines later in his Seven Ages of Man speech, after having witnessed Duke Senior's kindness to the belligerent Orlando, he has ceased his manic externalizing defense and is in the process of possessing his own multiplicity, imperfections, and vulnerability (ultimately, mortality). Jaques has moved from the paranoid-schizoid position, which sees both self and others in black/white, either/or terms as either purely good or purely bad, toward the depressive position, which realizes that both self and others are composed of many possibilities and that who or what they are changes as they live their lives.

Jaques does not immediately abandon his aggression once and for all. He returns to verbal aggression when he tells Orlando to stop posting his verses, invites Orlando to join him in railing against the world and their misery, and says it is a fault to be in love (see III.ii.252-74). However, several scenes later, when he is severely chided by Rosalind for being once again immersed in melancholy, he explains that unlike some forms of melancholy, which function in various ways as simply another means of self-aggrandizement, his depression derives from his broad experience of the world. When Rosalind glibly dismisses his travels as folly, he corrects her, asserting that the experience he gained from them is invaluable, despite the fact that it makes him sad. Most tellingly, when Rosalind continues to mock him, he does not respond with verbal aggression of his own, but simply retires upon the entrance of Orlando, as Rosalind's mockery of him continues (see IV.i.19-34). And at the end of the play, on hearing that Duke Frederick has renounced ambition and dominance and withdrawn into a life of solitude, Jaques determines that he will join him in a life of contemplation: "To him will I; out of these convertites / There is much matter to be heard and learned" (V.iv.182-83). Hence, after wishing the others well, he declares: "I am for other than for dancing measures" (V.iv.191), and departs to begin the contemplative life that will presumably enable him to attain the depressive position and the awareness of moral complexity and engagement in reparative action that it entails. The character of Jaques thus offers audiences a mascu- 
linity script of vulnerability $\rightarrow$ depression $\rightarrow$ (verbal aggression) $\rightarrow$ contemplation ( $\rightarrow$ depressive position $\rightarrow$ reparation).

\section{Conclusion}

As You Like It thus undermines the dominant paranoid-schizoid masculinity script by exposing its negative consequences and its defensive function, and it offers several scripts, through the actions of Touchstone, for enacting this aggressive, dominating masculinity more flexibly and benignly: pride $\rightarrow$ envy $\rightarrow$ verbal aggression (insult, threat, oblique criticism, or conditional accusation) $\rightarrow$ verbal putdown $\rightarrow$ psychological dominance. Most importantly, the play provides, in the actions of Duke Senior and others, a basic script for enacting the empathy and reparation of the depressive position (humility $\rightarrow$ responsibility $\rightarrow$ empathy $\rightarrow$ reparation $\rightarrow$ atonement, mutual flourishing), as well as three scripts for moving beyond paranoid-schizoid masculinity to the empathy and reparation of the depressive position. These scripts include: a) Oliver and Frederick: envy/aggression $\rightarrow$ epiphany $\rightarrow$ conversion $\rightarrow$ empathy $\rightarrow$ reparation; b) Orlando: splitting/idealization of the other (falling in love) $\rightarrow$ encounter with good external objects $\rightarrow$ relationship training $\rightarrow$ integration of empathy and subordination of aggression $\rightarrow$ reparation and relational commitment (marriage), and c) Jaques: vulnerability $\rightarrow$ depression $\rightarrow$ (verbal aggression) $\rightarrow$ contemplation $(\rightarrow$ depressive position $\rightarrow$ reparation).

These alternative scripts not only offer escape from the personal suffering and interpersonal violence produced by the scripts of dominant masculinity, they also constitute necessary and sufficient prerequisites for overcoming much of the collective violence perpetrated by social and political structures, institutions, policies, and actions, including war, poverty, and inequality. In Shakespeare's day, these masculinity scripts constituted an alternative to the belligerent, warmongering masculinity of men like Sidney and Essex. In our day, these same scripts offer an alternative not only to the belligerent, warmongering masculinity of politicians such as Bush, Cheney, and Rumsfeld, but also to the massive indifference toward the suffering of the underclass in the United States and around the world. For as Neil Altman has observed, the widespread abandonment of social responsibility in American society is the result of a collective defense "against precisely the depressive guilt that ... leads to reparative con- 
cern for others". ${ }^{29}$ Our entire society, Altman argues, has embraced the paranoid-schizoid position, splitting people into groups of good and bad, deserving and undeserving, and externalizing all negative qualities onto the latter groups, thus inviting and justifying the perpetration of various forms of violence (physical, institutional, structural, cultural) against them. Social responsibility demands that we eschew this paranoid-schizoid behavior and instead embrace the depressive position, recognizing our own complicity in the suffering of others at home and around the world and engaging in reparative action to ameliorate that suffering. ${ }^{30}$

Literary texts such as As You Like It can promote this movement to the depressive position and prosocial action, provided they are consumed in the right way. Simply reading or watching As You Like It will rarely result, in and of itself, in the acquisition by audience members of the more benign relational, reparative masculinity scripts. For such acquisition to occur, teaching must play a key role. Some may object that it is not the role of teachers to help students acquire alternative behavioral scripts. ${ }^{31}$ Recent developments in learning theory, however, suggest otherwise. Roger Schank, for one, argues that helping students acquire such scripts should be the central purpose of education: "We should teach cross curricularly with a focus on what we want students to actually be able to do in the real world", ${ }^{32}$ he advises, and this means that "we need to teach relevant scriptlets", ${ }^{33}$ by which he means specific scripts for cognition and action. Indeed, in Schank's view, "a curriculum ought to be no more than a collection of scriptlets to be acquired". ${ }^{34}$

Recalling that scripts are acquired by rehearsing them in multiple contexts in any of several various ways (for example, reading, recalling, imagining, performing), we can identify a number of basic pedagogical activities by which such acquisition can be maximized, including a) re-reading, remembering, and/or performing key scenes

${ }^{29}$ Neil Altman, "Manic Society: Toward the Depressive Position", Psychoanalytic Dialogues, XV/3 (June 2005), 330.

${ }^{30}$ See ibid., 329-31.

${ }^{31}$ See, for example, Stanley Fish, Save the World on Your Own Time, New York: Oxford University Press, 2008.

32 Roger C. Schank, Dynamic Memory Revisited, New York: Cambridge University Press, 1999, 180.

${ }^{33}$ Ibid., 184.

${ }^{34}$ Ibid., 185. 
from the play with attention focused on the relational, reparative masculinity scripts; b) rehearsing the relational, reparative scripts by viewing and reading other Shakespeare plays, and other literary texts, in which they are present; c) searching for and identifying the relational, reparative scripts in other texts, so that when one reads these texts, one is simultaneously consciously rehearsing these scripts; d) writing the relational, reparative scripts into other characters and circumstances, and e) imagining performing the relational, reparative scripts in real life. By engaging students in such activities, teachers can help them acquire alternative masculinity scripts that will not only enhance their chances for personal well being but will also contribute significantly to the general welfare. 